\title{
(I)literate Identities in Adult Basic Education: A Case Study of a Latino Woman in an ESOL and Computer Literacy Class
}

Juan Pablo Jiménez

\begin{abstract}
Adult Basic Education (ABE), namely English to Speakers of Other Languages (ESOL) in the United States has been understood and assessed as the mastering of skills increasingly aimed at meeting the demands of the workplace. This ethnographic case study examines how the literacy practices a Latino woman engages in through her participation in an ABE-ESOL class relate to her developing identities of mother, student and citizen. Using Critical Discourse Analysis (CDA), the findings demonstrate the contextual nature of adult literacy, showing how learners appropriate available tools and texts and enact purposeful and meaningful literacy practices, which traditional ABE assessment dismiss or do not account for. Implications for adult literacy pedagogy and research are discussed.
\end{abstract}

Keywords: ESOL, adult literacy, social practices, multiliteracies, textual mediation, identity

\section{Resumen}

La educación básica para adultos -por ejemplo, las clases de Inglés para hablantes de otras lenguas (ESOL)- en los Estados Unidos se ha concebido y evaluado como el dominio de habilidades básicas dirigidas a responder las demandas del mercado laboral. Este estudio etnográfico analiza cómo las prácticas textuales de una mujer latina en una clase de ESOL se relacionan con sus identidades de madre, estudiante y ciudadana. Usando el análisis crítico del discurso (ACD), los resultados demuestran la naturaleza contextual de la alfabetización para adultos, ilustrando cómo los estudiantes se apropian de herramientas y textos disponibles para desarrollar prácticas textuales útiles y significativas para ellos, las cuales ni son tenidas en cuenta ni reportadas en las evaluacines tradicionales. Por último, se discuten algunas implicaciones pedagogícas e investigativas en este campo.

Descriptores: ESOL, Educación para adultos, prácticas sociales, alfabetismo multiple, mediación textual, identidad

* Received: 06-05-07/Accepted 09-08-07 


\section{Introduction}

In a recent discussion on how the term "illiteracy" is used in the United States political discourse to justify particular forms of intervention in the life of individuals Clair and Sandlin (2004) argue that: "To be considered illiterate in contemporary America is not just to struggle with reading and writing - it is to be deemed unworthy, unproductive, a bad parent, and deserving remarkably high levels of domestic intervention" (p.46). Clair and Sandlin's argument demands critical examination in the present time of educational and welfare reform in the United States. Latino families are at the epicenter of the national political agendas, namely the current educational reform No Child Left Behind, with a strong call for school-family partnership focusing on issues of literacy, as well as the Workforce Investment Act, (1998) in which policymakers emphasize the need for a connection between adult education and work force development (Huerta-Macías, 2002).

The purpose of this paper is to report on a one-year ethnographic case study that attempts to achieve a holistic, contextualized understanding of the actual literacy practices a Latino woman engages in through her participation in an adult ESOL and computer Literacy class in a post-industrial Northeastern American city (a city whose economic has transitioned from a manufacturing based economy to a service based economy). Drawing on socio-cultural and poststructural perspectives on literacy, namely, the New Literacy Studies (Barton et al., 2000; Baynham, 1995; Gee, 1996; Luke, 1996; Street, 1993) and the notion of Multiliteracies proposed by the New London Group (1996), I first introduce the constructs of literacy as design (Cope et al., 2000; Kress $\varepsilon$ Van Leeuwen, 2001; New London Group, 1996) and identity in second language Literacy (Lam, 2000; McKay, 1996; Pierce, 1995; Weinstein-Shr et al., 1995). Next, I present the results from a case study of a Latino woman's literacy practices. I examine how her enacted literacy practices, both in and outside of the classroom, relate to her second language literacy development and identity formation. I describe how in the process of becoming the designer of her own literate events by consuming and producing texts, she constructs and repositions her multiple social identities within her culturally and linguistically diverse community.

The analysis shows how the focal student's contradictory literate identities are tightly bound to her immediate context and reveals how she appropriates the tools and text available to her, and engages in purposeful and meaningful 
literacy practices often overlooked by current literacy assessment methods (e.g. The Test for Adult Basic Education (TABE); and the Basic English Skills Test (BEST, among others $)^{\text {a1 }}$. This study raises critical issues in literacy development and adult identity for $\mathrm{ABE}$ teaching and research as current political agendas corral educational programs to blindly adopt standard assessment measures that dismiss non-traditional literacy practices in the name of accountability.

\section{Related Literature}

\section{Literacy development as socially and culturally situated}

Recent research on literacy, such as the New Literacy Studies (e.g., Barton, Hamilton E Ivanic, 2000; Baynham, 1995; Gee, 1996; Luke, 1996; Street, 1993) have brought attention to the importance of particular socio-cultural contexts and the way literacy is intimately bound up with institutions and social relationships. Literacy as a social situated practice "...is understood as a process by which the individual is socialized for group membership in specific literate communities and, in turn, participates in shaping the social practices of these communities" (Lam, 2000, p. 459) ${ }^{\mathbf{b} 2}$. Within this perspective, the New London Group has proposed a vision of literacy education - Multiliteracieswhich perceives literacy as a process of negotiating a multiplicity of discourses and plurality of texts that circulate in the context of today's cultural and linguistic diversity. The Design of meaning and the individual as the Designer (capitalization from original text) is a central concept in the New London Group's project (New London Group, 1996).

\section{Literacy as the Design of meaning and identity}

According to Gunther Kress (2000), one of the members of the New London Group, design involves the process in which students - as Designers orchestrate Available Designs (readily existing resources) such us texts, linguistic patterns, genres and discourses, through a potentially transformative process of Designing in order to achieve their communicative purpose. Consequently, the resources produced through this process - the Redesigned (a newly produced text) becomes a new Available Design, a new meaning making resource for other students or member of the social group. The authors of the New London Group argue "Through this process of Design, moreover, meaning makers remake themselves. They reconstruct and renegotiate their identities" (New London Group, 1996). 


\section{Social Identity and the Adult learner ${ }^{1}$}

Different studies (Kern, 2000; Lam, 2000; McKay, 1996; Pierce, 1995; Weinstein-Shr et al., 1995) have shown the connection between L2 literacy development and the construction of the learner's identity. For example, immigrant parents often experience a process of re-creation of parental identities when their children perform "adult" tasks for their parent such as talking with a landlord or paying bills (Weinstein-Shr et al., 1995).

In a study of adult ESL learners in Canada, Pierce (1995) developed the notion of investment to explain how the development of L2 literacy is highly influenced by the learner's relationship with the target language context. In addition, in her study, Lam (2000) states that "when language learners speak, they are not only exchanging information with target language speakers but are constantly organizing and reorganizing a sense of who they are and how they relate to the social world" (p. 460). Consequently, the process of identity constructions occurs in the everyday literate events and social actions in which learners engage through their participation in different domains of their immediate sociocultural context (home, classroom, church, community) and through the appropriation of already available resources such as texts and tools (Kress, 2000).

\section{Methodology}

This case study is part of a one-year ethnographic study that focused on developing an understanding of the literacy practices adult learners engage in through their participation in an ESOL and computer Literacy class in a post-industrial city in the Northeastern area of the United States. How is adult literacy being developed in the classroom based on the curriculum that the education program proposes and what students actually do in and outside of class? How do the literate activities of Jina - the focal student - (all names are pseudonyms) in the classroom relate to her multiple social identities? How is the focal student appropriating new literacies and available cultural tools for accomplishing her immediate communication needs? These were the driving questions of the study.

\section{The Social Context of the study}

Mills Town is a small city of approximately 40,000 residents with an increasing Latino population (45\% of city residents). According to ABE administrator in the city, almost 10,000 (25\%) of its residents need ABE (i.e. GED preparation, 
job readiness, ESOL, native language and family literacy) (JUNTOS Report, 2003). In addition, the local media often characterize the city as having high rates of poverty and unemployment, high drop out rates, and, according to recent standardized test results, an underperforming school district. Putting it all into perspective, the situation in Mills Town, is a reflection of the adult literacy demands in Massachusetts. According to the MassINC's New Skills for a New Economy report, (Comings, 2001) one-third (1.1 million) of the state's 3.2 million workers do not have the skills required by the state's rapidly evolving economy and need some sort of adult basic education.

\section{The ESOL and computer Literacy class}

Based on the above situation, the ESOL and Computer Literacy Class attempted to respond to several of the multiple educational needs in the city (e.g. ESOL support, Job readiness, family literacy). The class met twice a week for three hours each day, serving ten families represented by 11 adults (ages 28 to 56) and 14 children (ages eight to 16). There were eight women and eight girls in the program, while the men numbered three and the boys six. In terms of racial/ethnic composition of the class, there were 23 Latinos and two AfricanAmericans. In addition, it was a multi level class (in each of the three cycles there were new people joining the class), as well as a multi-subject class (a combination of ESOL and computer literacy) taught in English and Spanish.

The class used a participatory curriculum in which lifeskills instruction, student voice, and integration of technology were cornerstones of the instructional program. Students voted on lifeskills topics such as health, employment search, budgeting, welfare and community services, child's school and transportation to determine the context and content through which they will develop their ESOL speaking, listening, reading, and writing skills. In addition, I made every effort to make both the content of the course and our daily interactions within and outside of class reflect the learners' previous and current experiences. I also drew on the community resources such as the public library, local newspapers and everyday conversations about diverse community issues, in Moll's words, their "funds of knowledge" (Moll, 1992).

My role as the instructor and researcher in this class

I joined the ABE force in Mills Town in 2002, first as an ESOL instructor and then as a computer and family literacy instructor. As a Latino myself, I became very involved in trying to contribute to the improvement of the conditions of the Latino people in this community. As a believer in socially responsive education 
as a road to social change, I conceive teaching and learning in this community of adult learners as a situated practice (New London Group, 1996). Thus, I was an active participant fully immersed and engaged in this community. Therefore, after teaching the first cycle of the ESOL and computer Literacy class during the spring of 2003, I became very interested in finding out what the participating parents would do with their new knowledge in their day-to-day lives. For this reason, I decided to closely follow up the different activities in which the class participants, especially Jina, engaged in and outside of the class.

Data collection and Analysis

Beginning in the summer of 2003 to the Fall of 2004, I used techniques associated with qualitative or interpretative research methods for data collection and analysis. Namely, I used active participant observation techniques (Wolcott, 1988) in the domains of the home, the classroom and the church. With Jina's written consent, I videotaped all classes, conducted and recorded two in-depth semi-structured interviews that lasted over one hour each. For the second interview, I used a variation of the data collection technique of Interpersonal Process Recall (Kagan, 1980), which consists of playing video tapes back to participants to comment on any portion of the events they choose. In addition, I wrote extensive fieldnotes after each class, collected background documents and samples of student's work in class, as well as e-mail communications to include in the bulk of the data set.

Then, a macro/micro-analysis of the data was carried out. For the macro coding and analysis, I followed a systematic interpretative process analogous to a constant-comparative qualitative procedure (Glaser, 1978) to code video recordings and transcripts of class interactions, the two interviews, as wells as the different texts produced and used by Jina. Therefore, I was able to identify and follow two main umbrella thematic lines to which the emerging and reoccurring codes were associated to Jina's literate activities: 1) Jina's literate worlds, and 2) Jina's contradictory literate identities. Readers may assess the reliability of my categorization using criteria set forth by Moss (1994).

For the micro-analysis of pivotal texts (written and spoken) selected from the data set, I used the lens of Critical Discourse Analysis (henceforth CDA). CDA views "language as a form of social practice" (Fairclough 1989: 20). Fairclough articulated a three-dimensional framework for studying discourse, 
"where the aim is to map three separate forms of analysis onto one another: analysis of (spoken or written) language texts, analysis of discourse practice (processes of text production, distribution and consumption) and analysis of discursive events as instances of sociocultural practice" (1995: 2). Considering that this investigation focused on literacy as a dynamic and interactive process of consuming, producing and distributing texts, which is intrinsically bound to the construction of the learner's social identities in the everyday discursive practices; in the following analysis, I focus on how Jina expresses meanings in the structure of the language she uses in her oral recounts of key experiences and events related to the ESOL and Computer Literacy Class.

\section{Results}

Jina's Literate worlds

Jina became the focal student based on salient patterns of her behavior as an adult learner. Such patterns included class attendance, individual and family involvement, and mainly her contradictory attitudes in class. She seemed very interested in learning, and she expressed it several times, as in the closing of one of her e-mails "The Student That Wants to Learn" (Personal e-mail, September, 16, 2003). However, she often chose not to work on the proposed activities in the classroom.

Of Puerto Rican parents, Jina was born in Pennsylvania, but for economical reasons, her family moved to Mills Town when she was seven. As is true of many Latino families in this country, she grew up speaking Spanish at home but attended mainstream English-only classrooms until eighth grade, when she decided to drop out of school. A rather quiet woman in her late thirties, Jina was full of energy except on those cold evenings in the winter of 2003 when she would enter the classroom coughing or in the middle of an asthma attack. She is married to José, a Puerto Rican man, a pastor of a small Spanish speaking Pentecostal church in town. Jina is also the mother of four, two adult sons and two teenage daughters. Liz and Teresa (the daughters) attended the youth component of the ESOL and computer family literacy class with her. During the course of this study, Jina's literate worlds revolved around three main domains: her home, the family literacy class and her church; and three languages: English, Spanish and Spanglish - a hybrid language resulting from the mixture of English and Spanish. 


\section{Literacy at home}

As a mother, she was responsible for cooking, cleaning the house, taking her children back and forth to school and work, but most importantly, of handling virtually all literate demands in her household. From paying bills and making doctor's and church related appointments, to making sure her daughter's homework was done. At home, Jina addressed her children mostly in English and Spanglish. However, she always talked to her husband in Spanish. Similarly, her everyday literate activities such as reading bills and writing checks, as well as making appointments over the phone were both in Spanish and English. Nevertheless, whenever she read the bible, she preferred to do it in English.

\section{Literacy at church}

As the wife of a church pastor, Jina was responsible for ensuring that everything would be ready for their Tuesday, Thursday, Friday evening and Sunday services, from inviting people to attend the service to making photocopies and setting up the church room. During weekday afternoons, she led the "Grupo de Damas" to do door-to-door witnessing (professing her Christian religion) and home visits to church members, who either were sick or had missed church. On Sundays, she taught Sunday school in English to a group of about 15 children whose ages ranged between four to eight. In addition, as she stated in the draft of one of the class projects, she was responsible for other literate activities. "I' $m$ the bookkeeper and the organizer of events for this church. I also perform the secretarial tasks" which included typing, notes and fliers drafted in Spanish by her husband (Student text résumé draft December 1, 2003). Moreover, sometimes she was even responsible for preaching the gospel message in Spanish. As the pastora (the way she was called by the church goers) she explained "it would not be good if I do not preach" (Interview 1, Nov. 15, 2003).

\section{Literacy in the ESOL class}

Jina joined the ESOL and computer Literacy class during its second cycle in the summer of 2003. She attended every meeting even if her daughters did not come. Her investment in the class was evident in every aspect of her interaction with me, the tutors, or the rest of the students. In class, she spoke mostly English with the two Caucasian tutors and me. However, she spoke Spanish with most of her classmates who were native speaker of Spanish, and whose English was just at an emerging proficiency. 
During the individual computer skills entry assessment, Jina reported and demonstrated very little knowledge of computer literacy. She looked comfortable turning the computer on and off, using the mouse and most of the alphanumeric keys of the keyboard. However, she reported that when she needed to write something on the computer at home, she asked one of her children "to open the white page [a word processing blank document] for her." (Entry Assessment, July 15, 2003). Thus, it seemed evident that Jina could benefit greatly from the class curriculum as it was aimed at developing basic word processing and keyboarding skills, as well as introducing adult learners to electronic literacies such as e-mail and Internet browsing (Warschauer, 2000), while supporting students' English as a second language development.

As with all of the students, I expected Jina to be on task during class and to work hard on the completion of the class work. Nonetheless, I found it problematic when Jina displayed behaviors of resisting to work on and completing assignments, and even openly expressing her discomfort with the pace of the class "I think that sometimes we spend too much time on a topic" (fieldnotes, November 3, 2003). Paradoxically, she wanted to spend more time in class working on individual projects for her church and always asked me or the tutors for support. During the course of this study, it was evident that she was increasingly becoming the ad hoc secretary for the church. At almost every class meeting, she worked on church-related documents such as fliers, letters of invitation, and service programs, mostly in Spanish. Hence, I became interested in making sense of Jina's literate identities.

Jina's Contradictory literate Identities

Jina as Spanish illiterate: In ABE classrooms, as in any other educational setting, students construct and co-construct their multiple identities; for example, as a student of a particular classroom, or as a "knower" of expected classroom content and ways of being a student in that particular classroom through their everyday communication. The following excerpt is a classroom interaction between Jina and Zilmara, one of her classmates, right before leaving the classroom:

It is about 8:30 PM, class finished a few minutes ago. The video camera is still running and we are in the process of cleaning up the classroom. Jina tells Zilmara about her intentions to enter a native language literacy course in Spanish at the local community center where Zilmara is taking Intermediate ESOL courses. 
Transcription conventions:

Text within brackets and in italics is my translation from Spanish

(Texts within parenthesis are explanatory comments)

Jina: The focal student

Zilmara: Jina's classmate

(XXXXX) Inaudible speech

Boldface indicates items of analytic focus

Jina: $\quad$ Me pusieron en un waitin' list, me dijeron que habían muchos y me metieron así.

[They put me on a waiting list (for the ABE Spanish literacy class), they told me there are many people on it (the waiting list)]

Zilmara: Sí, es que te tienen que poner en un waitin' list porque las clases están llenas

[Yes, they need to put you on a waiting list because the classes are full]

Jina: $\quad Y$ cuándo entran otra vez?

[and when do you start classes again]

Zilamara: Creo que en enero

[I think that in January]

Jina: $\quad$ Pero yo sé muchas cosas, pero MUCHAS, muchas no las sé muy bien... pero ellos me pusieron en un watin' list

[But I know many things (in Spanish), but MANY, many things I do not know very well... but they put me on a waiting list]

$(\mathrm{XXXXX)}$

Zilamara: Pero tú sabes leer y escribir? [but do you know how to read and write?]

Jina:

Zilamara: =en español?

Jina:

$=$ Uh um!

=síun poquito, se leerlo

más que lo que escribo Tirsa sabe más, ella me ayuda.

[in Spanish? Yes, a little bit, I know how to read better than writing it. Tirsa (one of her daughters) knows more, she helps me]

This excerpt contains key aspects of particular interest to this study. First, it shows contradictory subject positions regarding Jina's Spanish literacy. For example, in lines 13 and 14, Jina first positions herself as a knower of many things in Spanish "Pero yo sé muchas cosas" but immediately contradicts herself by saying "pero MUCHAS, muchas no las sé muy bien... It is clear how Jina's subject position as a "non knower" is constructed with the help of Zilmara's immediate question Pero tú sabes leer y escribir? (line 18), which seems to be the first time Jina is asked such a revealing question regarding her command of the Spanish language. Specifically she is asked whether she can 
read and write in Spanish. Considering the fact the in the three main domains of home, church and the ABE classroom Jina uses Spanish mostly for oral communication, when asked this question in the context of the classroom, she faced a new subject position as an Illiterate person in Spanish. This is evidently stressed in her wording choices moving from "But I know many things" (line 13) to knowing just "a little bit" [in Spanish] (line 22).

Second, the excerpt shows not only that Jina is uncertain about her identity as a Spanish reader and writer but also, by referring to her daughter's knowledge of Spanish, Jina concedes her illiterate identity in the context of home. I wish to argue that through this interaction, Jina is positioned as an illiterate person in Spanish. She realizes that speaking Spanish is not enough for her to fully accomplish her social tasks both in the classroom and outside if it (e.g., at church or home) but most importantly, she completely disregards her extensive engagement with her everyday literacy practices. In essence, Jina admits her Spanish illiterate identity as being framed within the traditionally used and widely accepted social construction of illiteracy as incompetence in reading and writing.

Jina as Spanish Literate: One evening, after I introduced the class to different techniques for doing Internet searches, students worked on doing their own Internet searches. Jina was looking for specific information about the history of Halloween. She asked me about how to look for it and I reminded her about the importance of using keywords associated to the topic of interests. I suggested that she include among those keywords "Halloween origin." when she did an Internet search, she found lots of information and printed out a few of those pages. As agreed in class, she gave me copies of them. Three weeks later, at her house, during an interview she told me about how she was using those documents at church.

The following is an excerpt from an interview I conducted at Jina's home. In the first question, I asked Jina to describe what a typical day in her life was, while in the second question I asked her to talk about how she selected the different documents to work on while in the class and if she had used them outside of the class.

In the analysis, I am focusing on a personal narrative embedded in Jina's interview about a particular event, a drama, that she did at church for illustrating the message of what she preached. I'm using Denzin's (1989) definition of 
narrative as "a story of a sequence of events that has significance for the narrator and her audience... a beginning, a middle and an end, as well as a logic that (at least) makes sense to the narrator." (p. 37) as cited in Coffey and Atkinson (1996).

\author{
Transcription conventions: \\ $=\quad$ Latching between speakers words \\ (XXX) Inaudible speech \\ $((a b c)) \quad$ Texts within double parenthesis refers to non verbal information \\ [ $a b c] \quad$ Text within brackets are explanatory comments \\ Boldface and underline indicates items of analytic focus
}

Saturday, Nov. 15, 2003. 3:30 p.m. at Jina's house.

Juan Pablo: I also saw that (pauses and clear his throat) you gave me copies of, of, the documents that you copy and, and in the, ((pause)) you know having like messages,

Jina: Uh hum,

Juan Pablo: =like bible messages right, ah, ((pause)) now have you used those a lot in, in church? Or...

Jina: No um, the ones I gave you the other day (pause)) were, that day I ((pause))

'cause um, it was the day of Halloween I had to preach ((pause)) and instead of, that day! I didn't bring the Halloween staff, I brought it before that, and um 'cause when I talked about Halloween it was more like um, um ((pause)) un consejo, you know! a través de Halloween. But on the thirty first, [referring to October 31] um when I got that inf ((pause))

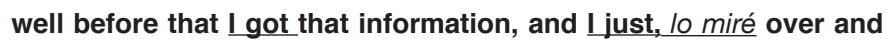
over and over, and, I did a drama with it ((laughs)) I did a drama with it, because it was talking about la venida de Cristo $y$ eso, so we did a drama with it. ("it" refers to the bible messages she found within an Internet cartoon when doing Internet searches in class)

Juan Pablo: So you, you kind of use the information

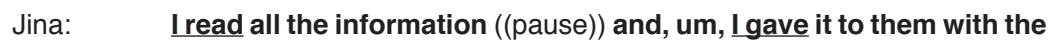
textos (biblical readings) you know?

Juan Pablo: people?, to what parents?

Jina: =to the whole church, to the whole church ((pause)) and it was the day of, for the big people everything the singing, the preaching, everything was for the adults that day. But everybody was in church that day ((pause)) and, um I preached, and then I, I told everybody that ((pause)) that there was gonna be a drama about what I preached, más o menos de lo que yo prediqué, and we did a drama right after 
The excerpt above (Lines 10 - 28) is about a drama as a particular event that took place during a Sunday service at Jina's church after she preached the gospel in Spanish. Through this narrative, Jina tells us about how she came up with the idea of creating a play for her preaching, whose function was to illustrate how she has used the available Designs (texts) and cultural artifacts in her work at church.

A micro-textual analysis based on Fairclugh's (1995) CDA framework, reveals how the above narrative is told from Jina's perspective through a reiterative use of first person: "when $\underline{I \text { got }}$ that inf... $\underline{\text { I got }}$ that information, and $\underline{I}$ just, lo miré over and over and over, and, I did a drama with it." Evidently, Jina is positioning herself not only as the leader in deciding what to do at church; but most importantly, as a very literate person as the author of both, the idea of the play and the written texts used for the preaching of the gospel.

Jina as a literacy and identity designer: A second level of analysis within CDA requires close observation of Jina's process of consuming, producing and distributing texts in order to try to answer the question of what were the discursive and literacy practices that Jina enacted in and outside of the classroom and how they related to her different social identities. This level of analysis entitles an examination of Jina's process of consuming available texts, putting then into the process of redesign, and coming up with a redesigned of her own in order to accomplish her social tasks at her different domains.

Therefore, in a semi-structured interview, I asked Jina to show me how she found the Christian website, which she is referring to in the above excerpt. The following intertextual analysis illustrates how she went from reading the information in English from the different websites to creating a drama for preaching the gospel's message at her church. In addition, this provides us with an understanding of Jina's complex literate world.

A basic search for "Halloween origin" returned about ,1,120 web results. Many of websites claimed to be Christian religious sites. For example, the fourth hyperlink claims to be based on the Handbook of Christian Feasts and Customs (Weiser, 1999). At the bottom of the seventh link, on the second page of results, there is a link that connects to another page titled "The Truth about Halloween"

(http://holidays.christiansunite.com/halloween.shtml, 2004). A couple of clicks later (following the "Back to other Halloween resources" heading), the 
reader will find a few other site links, one of which reads: "Creative Halloween Tract Usage Ideas. Creative ideas showing how to use Chick tracts to witness to the children coming in your door this Halloween." (ChristiansUnite.com,2004).

This webpage actually belongs to the Chick Tracts Publications Website (Chick, 2003) mentioned during Jina's first interview. This is a Christian website that has several cartoon-like stories aimed at those interested in promulgating the Christian religion. Jina read and used the "Happy Halloween" story for one of her church talks and, later she went back to the site to explore other stories. Then she found the "Here he comes" story. One major attraction for Jina was the fact that the site clearly invites the reader to see the same story in other languages:

Jina: $\quad$ You know what else I did with this? [Referring to the Internet website] Um ((long pause)) it gives you a choice of Spanish!

Juan Pablo: The same (website) story?

Jina: That's how it was easy for me to use it in church, I read the English (version) because I wanted to know what I was gonna read [for the church preaching]

(Interpersonal Process Recall Interview, Nov. 24/03)

Jina looked at the story in Spanish, but feeling uncertain about its content, read it in English as well. Once at home, and with the printouts from the website, she decided to look for the Biblical references (bible verses written next to the cartoon dialogue) and typed them into a two-page word document in Spanish. Finally, during the following Sunday service, which was the day she was responsible for preaching, Jina handed in copies of this word document to the audience while she was preaching. The biblical verses in this document were the bases for the content of the play that she created at church.

\section{Discussion}

What does all this have to do with second language literacy development and adult identity? One could argue that when comparing the contradictory ways Jina positions herself, first, in class during her talk with Zilmara, as an illiterate person in Spanish and then at church as a very literate person, not only making decisions about what to do but actually using multiple texts both in Spanish and English, it is quite evident that Jina lives a very complex literate world within her multiple and contradicting social identities. I wish to use Kern's (2000) definition of literacy as: 
... the use of socially-, historically-, and culturally situated practices of creating and interpreting meaning through texts... Because it is purpose-sensitive, literacy is dynamic and variable across and within discourse communities and cultures. It draws on a wide range of cognitive abilities, on knowledge of written and spoken language, on knowledge on genres, and on cultural knowledge (p. 16).

to illuminate this interpretation, and the claim that what Jina does in her literate world is based on her needs; specifically, what it is expected of her from her multiple subjectivities in the different domains of her life. As a literacy designer, she is consuming, producing and distributing texts for accomplishing her immediate communicative needs. She interacts with the different texts, making use of not only her linguistic skills but her cognitive and social processes. Through a dynamic use of her culturally and historically situated multiple literacies, Jina is interpreting diverse written and spoken texts in order to fulfill particular social purposes within her immediate community.

Regarding her identity, it is clear that Jina assumes contradictory subject positions depending on the social-cultural context where she is located. For example, in class she positions herself as a vulnerable literate person, not a knower of Spanish. Nonetheless, at church she assumes an active leader position not only as a knower of Spanish, but also as a knower of many other things including multiple genres, and discourses. These claims are supported by Lyotard's discussion of Wittgenstain's theory of language games to explain why and how Jina makes use of different language codes in the classroom and in church (showing a different language command in each place) but coherently reflecting her multiple identities. In Loytard's words: "The 'atomization of the social into flexible networks of language games' suggests that each of us may resort to a quite different sets of codes depending upon the situation in which we find ourselves (at home, at work, at church, in the street or pub...)" Lyotard cited in Harvey (Harvey, 1989), for instance, in Jina's case, at her home, in the ESOL classroom or at church.

\section{Implications}

The findings of this study suggest that the literate identities which policymakers and even adult educators assume of their students may actually reveal a simple and incomplete idea of who those learners are. Moreover, if ABE educators blindly accept the results of standard measures to assess adult literacy both for students' placement and for reporting learning gains, they may dangerously 
contribute to the denial of complex literate worlds of those adult learners whom they seek to help, thus reproducing social constructions of disfranchised adults as unworthy, unproductive, or bad parents (Clair E Sandlin, 2004).

I have drawn on Jina's data to argue that the literacy practices adults may engage in as well as their literate identities are tightly bound to their immediate context. Adults, as well as other second language learners, appropriate the tools and texts available to them, and engage in purposeful and meaningful literacy practices often overlooked by current literacy assessment methods. I believe there is a need for adult literacy educators to resist standardized assessment of adult literacy development as this merely reproduces simplistic accounts of literacy development and of what actually takes place in the everyday life of both the adult second language classroom and the adult literate worlds. Then the challenge is for educators and researchers to continue socioculturally-based studies, such the one presented here, to build a body of evidence which may influence policy makers in supporting program accountability initiatives in which innovative or non standard assessment practices are considered.

\section{Acknowledgements}

I am in Jina's debt for allowing me to enter her literate worlds. Many thanks to the Holyoke Adult Basic Education administrators for granting me permission to carry out this research project, and to the anonymous reviewers who provided me valuable and useful comments on earlier versions of this manuscript.

\section{References}

Barton, D., Hamilton, M., \& Ivanic, R. (2000). Situated literacies: Reading and writing in context. London; New York: Routledge.

Baynham, M. (1995). Literacy practices: Investigating literacy in social contexts. London; New York: Longman.

Chick, J. T. (2003) Here he comes! Retrieved December 13, 2004, from http://www.chick. com/reading/tracts/5025/5025_01.asp

ChristiansUnite.com. (2004). The truth about Halloween! Retrieved December 13, 2004, from http://holidays.christiansunite.com/halloween_web_sites.shtml 
Clair, R., and Sandlin, J.A. (2004). Incompetence and intrusion: On the methaphorical use of illiteracy in U.S. Political discourse. Adult Basic Education, 14(1), 45-59.

Coffey, A., \& Atkinson, P. (1996). Making sense of qualitative data: Complementary research strategies. Thousand Oaks: Sage Publications.

Comings, J., Sum, A., Uvin, J. (2001). New skills for a new economy: Adult education's key role in sustaining economic growth and expanding opportunity. Boston: The Massachusetts Institute for a New Commonwealth.

Cope, B., Kalantzis, M., \& New London Group. (2000). Multiliteracies: Literacy learning and the design of social futures. London; New York: Routledge.

Denzin, N. K. (1989). Interpretive interactionism. Newbury Park, Calif.: Sage Publications.

Fairclough, N. (1989). Language and Power. Harlow: Longman.

Fairclough, N. (1995). Critical discourse analysis: The critical study of language. London: Longman Group.

Gee, J. P. (1996). Social linguistics and literacies: Ideology in discourses (2nd ed.). London; Bristol, PA: Taylor \& Francis.

Glaser, B. (1978). Theoretical sensitivity: Advances in the methodology of grounded theory. Mill Valley, CA: Sociology Press.

Harvey, D. (1989). The condition of postmodernity: An enquiry into the origins of cultural change. Oxford [England]; Cambridge, Mass., USA: Blackwell.

Huerta-Macías, A. (2002). Workforce education for Latinos: Politics, programs, and practices. Westport, Conn.: Bergin \& Garvey.

JUNTOS Report. (2003). An overview of ABE needs and assets in Holyoke, Massachusetts. Holyoke: JUNTOS Collaborative.

Kagan, N. (1980). Interpersonal process recall: A method of influencing human interaction. Houston: University of Houston, IPR Institute.

Kern, R. (2000). Literacy and language teaching. Oxford; New York: Oxford University Press.

Kress, G. R. (2000). Design and transformation: New theories of meaning. In B. Cope, \& M. Kalantzis (Ed.), Multiliteracies: Literacy learning and the design of social futures. London; New York: Routledge.

Kress, G. R., \& Van Leeuwen, T. (2001). Multimodal discourse: The modes and media of contemporary communication. London; New York: Oxford University Press.

Kruidenier, J., Partnership for Reading Project, \& RMC Research Corporation. (2002). Research-based principles for adult basic education reading instruction. Washington, D.C.: Partnership for Reading.

Lam, W. S. E. (2000). L2 literacy and the design of the self: A case study of a teenager writing on the Internet. TESOL Quarterly, 34(3), $457-481$.

New London Group. (1996). A pedagogy of multiliteracies: Designing social futures. Harvard Educational Review, 66(1), 60-91.

Luke, A. (1996). Genres of power? Literacy education and the production of capital. In R. Hassan \& G. William (Eds.), Literacy in society (pp. xxi, 431). New York: Longman. 
McKay, S., \& Wong, S. L. (1996). Multiple discourses, multiple identities: Investment and agency in second-language learning among Chinese adolescent immigrants students. Harvard Education Review, 66, 577-608.

Moll, L. (1992). Bilingual classroom studies and community analyses: Some recent trends. Educational Researcher, 21, 20-24.

Moss, P. A. (1994). Can there be validity without reliability. Educational Researcher, 23(2), 5-12.

Pierce, B. N. (1995). Social identity, investment and language learning. TESOL Quarterly, 29, 9-32.

Quigley, B. A. (1997). Rethinking literacy education: The critical need for practice-based change (1st ed.). San Francisco: Jossey-Bass Publishers.

Street, B. (Ed.). (1993). Cross-cultural approaches to literacy. Cambridge: Cambridge University Press.

Ullman, C. (1997). Social identity and the ESL classroom. ERIC Digest Retrieved November, 2004, from http://www.cal.org/ncle/DIGESTS/Socident.htm

United States Employment and Training Administration. (1998). Workforce investment act of 1998. Washington, D.C.: The Administration.

Warschauer, M. (2000). Online learning in second language classrooms: An ethnographic study. In M. Warschauer, \& R. Kern (Ed.), Network-based language teaching: Concepts and practice. New York: Cambridge University Press.

Weinstein-Shr, G., Quintero, E. P., \& National Clearinghouse for ESL Literacy Education. (1995). Immigrant learners and their families: Literacy to connect the generations. McHenry, IL: Center for Applied Linguistics and Delta Systems.

Weiser, F. X. (1999). Handbook of Christian feasts and customs: The year of the lord in liturgy and folklore. Colorado Springs, CO: Seraphim Co.

Wolcott, H. (1988). Ethnographic research in education. In R. M. Jaeger (Ed.), Complementary methods for research in education (pp. viii, 480). Washington, DC: American Educational Research Association.

\section{(Endnotes)}

a ${ }^{1}$ For an overview of the ABE assessment debate see Kruidenier et al., 2002; and Quigley, 1997.

b ${ }^{2}$ For further reading, see also Cushman, 1998; Heath, 1983; Ivanic, 1998; Scollon \& Scollon, 1981; Scribner \& Cole, 1981.

c ${ }^{3}$ Ullman, (Ullman, 1997) concisely describes theories on social identity and language learning and suggests practical ways in which adult educators might support the exploration of social identity issues in the process of second language learning. 


\section{THE AUTHOR}

Juan Pablo Jiménez Caicedo, Doctoral candidate in Language Literacy \& Culture (School of Education at the University of Massachusetts, Amherst) and M.A. in Foreign Languages and Cultures (Washington State University). He has taught EFL/ESL in Colombia and the United States and is currently teaching Spanish as a foreign language at the Spanish and Portuguese Department at Smith College. His research interests include second language acquisition and literacy development, sociocultural theories of learning, systemic functional linguistics, and the professional development of language teachers. He is currently looking at genre-based pedagogy and academic literacy on the inner city schools in Western Massachusetts with elementary English language learners. E-mail:.jimenez@educ.umass.edu 